\title{
SOCIAL RIGHTS AS FUNDAMENTAL RIGHTS AND THE JUDICIALIZATION OF POLICIES: SOME CONSIDERATIONS
}

\author{
Rodrigo Garcia Schwarz
}

\begin{abstract}
The effective constitutional recognition of social rights, by itself, establishes - in any circumstance, even in times of economic crisis - a "hard" nucleus, unavailable to the various public and/or political agents and authorities (including the courts) in terms of meeting social demands, in a manner that this minimum will constitute, in the action of these various agents and authorities, including in the scope of the Public Administration's actions, an insurmountable barrier that requires permanent boundaries and a certain integration between justice and politics, among judges, legislators and administrators. The judiciary, however, must guide its action by the search for possible mediation between guaranteeing the rights of all, the principle of separation of powers and balancing the budget.
\end{abstract}

KEYWORDS: control; social rights; judicialization of policies; public policies.

\section{RESUMO}

O efetivo reconhecimento constitucional dos direitos sociais, por si só, determina, em qualquer circunstância, e mesmo em tempos de crise econômica, um núcleo "duro", indisponível para os diversos agentes e poderes públicos e/ou políticos (inclusive os órgãos jurisdicionais) em matéria de atendimento às demandas sociais, de forma que esse mínimo constituirá, na ação desses diversos agentes e poderes, inclusive no âmbito da ação da Administração Pública, uma barreira intransponível que obriga a uma permanente delimitação e demanda certa integração entre justiça e política, entre magistrados, legisladores e administradores. O Judiciário, no entanto, deve pautar a sua ação pela busca da mediação possível entre a garantia dos direitos, o princípio da divisão dos poderes e o equilíbrio orçamentário.

PALAVRAS-CHAVE: controle; direitos sociais; judicialização de políticas; políticas públicas.

* Doutor, Pós-Doutor (Direito, História). 


\section{INITIAL CONSIDERATIONS}

The speed with which political and economic scenarios change, coupled with the growing complexity of contemporary society, has required a thorough reassessment the role of law and legal institutions in the social body. That markedly conservative juridical model, which is often indifferent to pressures from the popular masses and to the struggles for the right to have rights, hostile to judicial protection and control mechanisms with regard to acts of the Public Administration and its agents, and especially to the design and implementation of public policies, has gradually been superseded by a (new) model of an inclusive and markedly social State, which assumes onerous obligations (of effective intervention) towards its citizens and, in its attempt to fulfill such obligations, dialogues with and meets the demands of a wide range of social groups. In this context, the existence of a continuum between some rights and others - including civil, political and social rights - is generally admitted, which does not mean that their inherent obligations or the nature of their formulation is able convert them into rights subject to legislative definition, or into rights whose effectiveness depends on the discretionary authority of public administrators.

\section{SOCIAL RIGHTS AS FUNDAMENTAL RIGHTS}

The United Nations Committee on Economic, Social and Cultural Rights has maintained that public authorities have the obligation to ensure, at all times, even in times of crisis or factual difficulties, at least the essential contents of each social right, even imposing. In fact, the Committee has gone as far as imposing upon States and the various spheres of Public Administration a duty of non-regression as it concerns social rights ${ }^{1}$. Likewise, different laws

\footnotetext{
${ }^{1}$ According to the United Nations Committee on Economic, Social and Cultural Rights, this duty of non-regression is imposed even in times of economic crisis, so that "despite the externally caused problems, the obligations arising from the Pact continue to apply and are perhaps more relevant during times of economic contraction. Therefore, it seems to the Committee that a general deterioration of living conditions (...), which would be directly attributable to the general policy decisions and legislative measures of the Member States, and in the absence of
} 
establish the obligation of States to respect the minimum or essential content of the rights recognized in constitutions or international agreements and treaties (including those that are known as social i.e., economic, social and cultural rights), content that is conditioned by the context in which the law is applied and is subject to continuous redefinition over time, which cannot be delegated, however, to the will of the social agents at a given time. In any case, this minimum will always be an insurmountable barrier, which requires permanent boundaries and demands a certain integration between justice and politics, between judges and legislators and administrators.

Therefore, social rights are enforceable rights, although, in one way or another, their full effectiveness is highly contingent upon the legislative interventions and actions of the Executive, including through the management and implementation of public policies. They are jurisdictional rights, and can thus be demanded before a court and protected by it. That means that the violation of such rights cannot go unpunished, and a mechanism must be established to demand the legislative and/or administrative bodies to somehow offer a public justification for their failure to enforce these rights, and, consequently, for their legitimacy/illegitimacy.

In this context, we must note the phenomenon known as the "juridification surge" (Verrechtlichungsshüb), which, as we discuss in paper, consists of the expansion, diversification and sophistication of the mechanisms by which the public authorities, especially the Judiciary, began to interfere in social relations, usually conceived as belonging to the realm of the market or customs, their limits and implications ${ }^{2}$.

This underlying idea of this paper is that, by itself and in any circumstance, including in times of economic crisis, the effective constitutional recognition of social rights, establishes a nucleus that is unavailable to the various public and/or political agents and/or politicians, including the courts. We defend that social rights are enforceable and fully jurisdictional rights - that is, they are rights

concomitant compensatory measures, would contradict the obligations arising from the Pact" (General Comment n. 4, 1991).

${ }^{2}$ Regarding this "juridification surge" (Verrechtlichungsshüb), see SCHWARZ, R.; THOMÉ, C. Judicialização e administração pública no Brasil: notas a respeito da concretização dos direitos fundamentais sociais. Sociedad y discurso, Aalborg, n. $28,2015$. 
that can be demanded before a court, and protected by it. Thus, public policies, along with the criticisms that are usually made to refute the action of the courts, such as the alleged lack of democratic legitimacy by the courts and the alleged technical incompetence of judges to address economic issues (criticisms that are not entirely unfounded), can and should be subject to control by the Judiciary, which must, however, guide its action by the search for a possible middle ground between guaranteeing civil, political and social rights, the principle of separation of powers - which in fact amounts to the separation of roles and responsibilities - and balancing the budget.

The justiciability of a right and, consequently, of a public policy must therefore be analyzed based on several factors, including preventive, punitive or control aspects, even if all such aspects are aimed at enforcing punishment for the violation of a right, establishing a mechanism which, in one way or another, requires the legislative or administrative bodies to offer a public justification for failing to enforce such rights, and thus for the illegal nature of such omission. In short, we start from the premise that courts can and should control the reasonability of the responses of public authorities to social demands, while respecting the principle of separation of powers - which in fact amounts to the separation of roles and responsibilities - and considering the consequences of their decisions, including taking note of the principle of proportionality, but without shying away from its duty to enforce the civil, political and social rights recognized by the Constitution.

\section{CRITIQUE OF THE CONSERVATIVE VIEW OF SOCIAL RIGHTS AS ENFORCEABLE AND JURISDICTIONAL RIGHTS}

\subsection{The cost and benefit dimension of rights}

While civil and political rights are traditionally identified as rights that are negative, of low cost to the State, easily enforceable, and easy to protect, social rights are usually referred to as positive, financially burdensome, vague, indeterminate and of indirect efficacy, conditioned in their realization by reasonableness or availability criteria to the proviso of the possible, that is, to contingencies, 
especially economic-financial contingencies, in a clear context of disputes for the allocation of resources. According to this viewpoint, social rights constitute mere governing principles or programmatic clauses, being relegated to the will of the legislative and executive bodies, and, due to their collective nature, are not subject to certain forms of protection before the courts, which, faced with the proviso of the possible, should do nothing to guarantee them ${ }^{3}$.

Many of these viewpoints provide historical and axiological arguments for their justification. But the fact is that the same arguments used to support a weakened view of social rights can easily be extended to all rights, including civil and political rights.

The claim that civil and political rights usually generate negative and inactive obligations, and are therefore "cheap" and easy to defend, as opposed to the positive nature of social rights, which require intervention and are "expensive" and difficult to protect, is not tenable, because neither civil nor political rights can be characterized as negative rights, which imply inaction, nor can social rights be characterized strictly as positive rights, implying intervention.

Civil and political rights are also positive rights, which imply the provision of benefits. Thus, property rights, for example, do not only demand, as the classical liberal viewpoint would tend to assert, the absence of arbitrary interference by the State, but rather a large number of inherently costly public benefits, ranging from the creation and maintenance of various types of registries (for example, automotive, real estate or industrial property) to the creation and maintenance of security forces and courts that can enforce contracts involving ownership.

The political right to vote also involves a large and costly infrastructure, which includes everything from minor items, such as ballots and voting machines, to more complex ones, such as challengers, counting, recounting and registration mechanisms, logistics, election courts, etc.

In short, all civil and political rights, as is the case with social rights, have a distributive dimension, which demands multiple

${ }^{3}$ Concerning different variations of this formulation, see ABRAMOVICH, V.; COURTIS, C. Los derechos sociales como derechos exigibles. Madrid: Trotta, 2002, pp. 21 et seq.). 
resources, both of financial and human nature ${ }^{4}$. Therefore, the issue is not usually how to guarantee "expensive" rights, but rather to decide how and with what priority society must allocate the resources that all civil, political and social rights require for their fulfillment.

Likewise, social rights, while usually associated with benefits (positive rights), also include duties of inaction. Thus, the right to housing concerns not only a demand for policies that make access to housing possible, but also the right to not be arbitrarily evicted and to not have unfair terms included in the lease or purchase agreements for the residential property. The right to work is fundamentally related to protection against arbitrary dismissals, which implies a duty of inaction by employers.

Although related to social rights, these negative obligations do not require large expenditures, nor are they included in the so-called "proviso of the possible." In addition, many positive obligations related to the fulfillment of rights in general - be they civil, political or social - are not related with factual benefits, but rather with normative benefits (such as laws), which, without direct costs, simply create a regulatory framework that guarantees such rights. On the other hand, while they may be crucial to the fulfillment of certain rights, even some factual benefits do not have an exorbitant cost, such as those intended to establish local mechanisms of popular consultation and participation.

In short, we can state that all civil, political and social rights, in one form or another, constitute obligations of the public authorities that are enforceable, negative, of inaction or respect, and positive, of intervention or fulfillment, and, further, obligations concerning their protection against violations of actions or omissions by individuals 5 .

${ }^{4}$ The idea that all rights have a cost is the central argument of HOLMES, S.; SUNSTEIN, C. The cost of rights: why liberty depends on taxes. New York: Norton, 1999.

5 Shue distinguishes the broad range of obligations arising from all civil, political and social rights, for the public authorities, concentrating primarily on three obligations: to avoid, to protect, to aid (SHUE, H. Basic rights: subsistence, affluence and U.S. foreign policy. New Jersey: Princeton University, 1980, pp. 52-3). 


\subsection{The duties of non-regression and progressivity}

On the other hand, one of the main obligations that social rights generate for the public authorities is a negative duty, embodied in the principle of non-regression, which, according to the United Nations Committee on Economic, Social and Cultural Rights, obligates public authorities not to adopt policies and nor sanction any laws that worsen the situation of social rights in the country without any reasonable justification ${ }^{7}$.

This same principle of irreversibility of social achievements was constitutionally articulated after Germany enacted the Fundamental Law of Bonn (1949) as a corollary of the normative force of the constitution, and of the minimum or essential content of the rights recognized in it, and it propagated to various legal systems, such as those in Portugal $^{8}$, Spain, Colombia, Brazil and France.

6 The United Nations Committee on Economic, Social and Cultural Rights is the body responsible for overseeing compliance with the International Covenant on Economic, Social and Cultural Rights (ICESCR) (1966).

${ }^{7}$ In this sense, according to the United Nations Committee on Economic, Social and Cultural Rights, "The principal obligation of result reflected in article 2 is to take steps 'with a view to achieving progressively the full realization of the rights recognized in the Covenant. The term 'progressive realization' is often used to describe the intent of this phrase. The concept of progressive realization constitutes a recognition of the fact that full realization of all economic, social and cultural rights will generally not be able to be achieved in a short period of time. In this sense, the obligation differs significantly from that contained in article 2 of the International Covenant on Civil and Political Rights which embodies an immediate obligation to respect and ensure all of the relevant rights. Nevertheless, the fact that realization over time, or in other words progressively, is foreseen under the Covenant should not be misinterpreted as depriving the obligation of all meaningful content. It is on the one hand a necessary flexibility device, reflecting the realities of the real world and the difficulties involved for any country in ensuring full realization of economic, social and cultural rights. On the other hand, the phrase must be read in the light of the overall objective, indeed the raison d'être, of the Covenant which is to establish clear obligations for States parties in respect of the full realization of the rights in question. It thus imposes an obligation to move as expeditiously and effectively as possible towards that goal. Moreover, any deliberately retrogressive measures in that regard would require the most careful consideration and would need to be fully justified by reference to the totality of the rights provided for in the Covenant and in the context of the full use of the maximum available resources" (General comment n. 3, 1990).

${ }^{8}$ In Portugal, Canotilho points to the existence of implicit constitutional clauses that 
The notion of non-regression does not deprive the State of the possibility of promoting certain reforms within its social policies, which at first sight may seem regressive, such as (re)allocating the resources needed for the social inclusion of the most vulnerable groups. But the public authorities must always demonstrate to its citizens that the changes that they seek to promote will result in the greater protection of social rights.

The reasonableness or proportionality of a program or apparently regressive action on social rights can be assessed based on specific criteria, in order to allow the State to justify the program or policy, without prejudice to the recognition of a minimum nucleus that must be absolutely protected ${ }^{9}$, which is not subject to any limitations, however "proportionate." There are basic elements that incorporate the "test" of proportionality in some contemporary legal systems, such as the German one, which we can resort to by means of comparative law. These criteria include: (a) the legitimacy of the measure in question, that is, its relation to the legal order and, above all, to the proscribed purposes; (b) the suitability of the measure in question, that is, its genuinely adequate character for the protection of proscribed purposes; (c) the need for the measure in question, that is, its essential character and, above all, the absence of less burdensome means for the rights affected; and (d) the proportionality, in a strict sense, of the measure in question, that is, whether more benefits and advantages of general interest are derived than from other goods and values in conflict.

The obligation of non-regression when it comes to social rights is related to a duty of progressivity. This principle empowers public authorities to adopt programs and policies for the gradual development of social rights, insofar as resources are available (proviso of the possible), but it deprives States of the authority to indefinitely postpone the fulfillment of such rights. On the contrary, it demands concrete actions, starting by States demonstrating that they are actually making the best efforts, and to the maximum of

prohibit a "reactionary evolution" or "social regression" (CANOTILHO, J. G. Direito constitucional e teoria da constituição. Coimbra: Almedina, 1999, p. 449).

9 On the so-called "absolute theories" of the essential content of rights, see ALEXY, R. Teoría de los derechos fundamentales. Translated by Ernesto Garzón. Madrid: Centro de Estudios Constitucionales, 1994, pp. 288 et seq. 
available resources - human, financial, technological, etc. - to at least provide the essential content of social rights, and to prioritize solutions to groups in more vulnerable situations.

\subsection{Proviso of the possible}

Budget restrictions alone cannot be accepted as a strong enough argument for failing to implement fundamental social rights. Although public resources may be limited, the State must allocate specific budget items for the fulfillment of social rights, within its capabilities, but always employing its best efforts to guarantee the social rights of its citizens.

In short, if the idea of the proviso of the possible can be used by governments as an argument for its citizens in a context of disputes over available resources in order to justify the failure to implement certain social rights, if all civil, political and social rights are, to a greater or lesser degree, burdensome, and if what is really at stake is to decide how and with what priority the authorities will allocate the resources needed to fulfill all civil, political and social rights. Thus, when invoking the proviso of the possible, the authorities must always demonstrate that they are making their best possible efforts (at all levels, such as financial, personal, technological, etc.), and that it is prioritizing the most vulnerable groups.

Here, we see a clear mandate directed at the political authorities: if there is a more vulnerable group and resources are in fact limited, all possible policies must be directed first to meet the needs of such group. In this context, the justification of proviso of the possible contains a comparative judgment between what cannot be done and what is being done, and always demands that the use of maximum resources be demonstrated: for example, when a government has a budget surplus, it has no justification for exposing people to undignified living conditions based on the proviso of the possible.

\subsection{Definition of the minimum content of rights}

On the other hand, social rights are usually characterized as "vague" or indeterminate rights. Thus, formulas such as the "right to work" say very little about the actual content of the right in question, 
as well as the obligations arising thereof, which is why social rights classically entail some duties of result, leaving the concrete action mechanisms used to achieve them undefined. On the contrary, civil and political rights would not only determine the result to be pursued, but would at least indicate the means necessary to prevent their violation.

Again, the arguments suggesting that social rights are rights that are difficult to protect are not tenable. A certain degree of indetermination, even in semantic terms, is inherent not only in legal language, but in natural language itself. In the case of rights deemed as fundamental, enshrined in international treaties or at the constitutional level, such indetermination may even arise from a requirement derived from legal pluralism, since excessive regulation of the content and obligations arising from a right could curtail the democratic space of social dialogue concerning its scope ${ }^{10}$. Thus, neither the relative flexibility in the formulation of social rights results in making them unintelligible, nor is indetermination an insurmountable barrier.

Terms that are dear to classical civil rights, such as honor, property and freedom of expression, are no less obscure or more precise than those commonly used in the context of social rights. All rights come from a "nucleus of certainty," conventions and hermeneutic practices that are certainly not static but rather dynamic, and which therefore include, at any time, the possibility of interpretive development and of "gray areas." In these contexts, if most of the enlightening efforts of legislative, judicial and doctrinal activity are aimed at civil and political rights, it does not speak to a greater structural obscurity of social rights, but to a deliberate and clearly ideological choice. ${ }^{12}$

Nothing, therefore, prevents the development of criteria or indicators that delineate the most appropriate meaning of a given social right. Instead, more than just being desirable, establishing such

\footnotetext{
${ }^{10}$ For more on this matter, see the report prepared by Mary Daly for the European Committee for Social Cohesion (DALY, Mary. Access to social rights in Europe: Council of Europe Report. Lisbon: Ministry of Social Security and Work, 2003).

${ }^{11}$ For more on this matter, see HART, H. El concepto del derecho. Translated by Genaro Carrió. Buenos Aires: Abeledo-Perrot, 1963.

${ }^{12}$ Cf. ALEXY, R. Opus cit., p. 490.
} 
parameters or indicators is essential for control over the State's fulfillment of its social rights obligations, including to distinguish whether failure to comply with an obligation is due to lack of capacity or lack of political will. Or even to verify whether, in a particular legal order, a situation of regression, stagnation or progression in terms of social rights has been produced over a certain period of time. In addition, inaccurate, incorrect or even falsified data tend to be decisive elements in many social right violations. The existence of sufficient resources to finance a public policy, or the lack thereof, and the support of criteria for the development, application and evaluation of policies, based on arguments such as reasonableness and adequacy, are matters subject to proof, including through statistical data, and to whose arguments can always be opposed with other arguments.

Many of these criteria are what we call soft law, that is, they constitute merely interpretative guidelines, which, despite having a legal structure, are not required. However, its invocation by the holders of the right and their consideration by the public authorities could efficiently contribute to the definition of the content of social rights and the obligations arising therefrom, both for public authorities and for individuals.

In this sense, for example, several courts have developed the thesis of minimum or essential social rights, obligatory for both public authorities and private actors, under international law or within the framework of the constitutional provisions. Thus, the German Constitutional Court held that, even though social rights were not explicitly enshrined in the Fundamental Law of Bonn, a vital existential minimum can be derived from it, whether related to the principle of a person's dignity ${ }^{13}$, or related to the principle of material equality ${ }^{14}$ or to the principle of the social state ${ }^{15}$. Likewise,

13 "1. Die Würde des Menschen ist unantastbar. Sie zu achten und zu schützen ist Verflichtung aller staatlichen Gewalt" (The dignity of the human person is intangible. All public powers are required to respect and protect it).

14 2.2: "Jeder hat das Recht auf Leben und körperliche Unversehrtheit. Die Freiheit der Person ist unverletzlich. In diese Rechte darf nur auf Grund eines Gesetzes eingegriffen werden" (Everyone has the right to life and physical integrity. A person's liberty is inviolable. Only the law may restrict such right).

15 20.1: "Die Bundesrepublik Deutschland ist ein demokratischer und sozialer Bundesstaat" (The Federal Republic of German is a democratic and social federal State). 
when analyzing the constitution, the Colombian Constitutional Court deduced the right to a "vital minimum," composed of the goods and services that are needed for a dignified life, especially in urgent situations ${ }^{16}$, extending the scope of this "minimum" to the definition of rights such as health, housing and social security. Thus, neither the determination of the content of social rights, nor the definition of the actions required to realize such rights, nor the identification of the obligated subjects are matters beyond the scope of the courts.

\subsection{Binding upon private actors}

We emphasize that social rights oblige state authorities, whether at the Executive, Legislative or even the Judiciary level, but they can also oblige private actors, such as employers, health or education service providers, and fund, retirement and pension managers. Private actors are bound to fundamental rights either by the express recognition of the constituent ${ }^{17}$ legislator, or by various legal principles: from a ban on discrimination and bona fide clauses to the principle of protection of the contractual party or the social function of property.

Of course, the obligations pertaining to social rights do not apply equally to all private actors, especially because not all private individuals in charge of providing goods and services are in the same situation of power and supremacy with respect to third parties. Thus, the degree of attachment to which private actors are bound to observing and fulfilling social rights is directly and proportionally related to their size, influence and resources ${ }^{18}$.

\footnotetext{
16 "Esta vinculación entre el concepto de mínimo vital y las situaciones de urgencia constitucional fue analizada por la Corte [Constitucional de Colombia], por ejemplo, en su Sentencia T-1150, de 2000, sobre desplazamiento forzoso" (ÁVILA, J. El mínimo vital en la jurisprudencia de la Corte Constitucional. Bogotá: Cinep-Diakonia, 2002, p. 163).

17 Article 18.1 of the Portuguese Constitution, for example, provides that "The constitutional precepts regarding rights, freedoms and guarantees are directly applicable and bind public and private entities."

${ }^{18}$ For example, this is the criterion for binding private actors established by the Promotion of Equality and Prevention of Unfair Discrimination Act (2000), a South African law for the promotion of equality and the prevention of unfair discrimination.
} 


\subsection{Summary: Social rights as fundamental rights}

In short, all fundamental rights, be they civil, political or social in nature, have a complex constitution, a positive part, a negative part, and all rights entail some sort of financial cost, just as all rights are subject to judicialization. We do not deny that, on a case-by-case basis, certain elements may have a stronger symbolic effect than others, and that benefit rights, which in fact require larger expenditures, are more difficult to guarantee than other rights that do not require such high costs, whether due to financial and budget matters, or to the conflicting nature of the contributions and transfers of resources within a framework of disputes over resources. However, what we emphasize is that none of these problems pertains solely to social rights. Instead, such issues are found in relation to all fundamental rights, whether civil, political or social. Thus, if on the one hand, no one would nowadays claim that freedom of expression entails free and unconditional access to media, radio and television, we cannot reasonably say that, in a democratic environment, the right to housing or health would entail the automatic and unconditional duty of the public authorities to provide free housing or medicine to all persons and under any circumstances.

However, since what is at stake are since fundamental rights, and not just revocable concessions, the powers in charge must observe a series of obligations that cannot be postponed indefinitely: from the duty of non-regression with regards to social rights to adopting measures to protect social rights in light of abuses by private actors in power relations, without prejudice to the duty of permanently guaranteeing the minimum content of social rights, related to what is defined as the existential minimum, including culturally.

From this perspective, the addition of a person's expectations, of living a dignified life, of preserving their health or deciding about their own life plans, to the catalog of civil or social rights is simply a matter of procedure, or almost of semantics. A strict categorization would require admitting the existence of a continuum between all rights, without allowing the obligations contained therein, or the more or less indeterminate nature of their formulation, to become true elements of categorical differentiation. Therefore, the focus 
should be not on opposing civil and political rights to social rights, but to highlight the contrast between rights that can be generalized and exclusionary privileges.

Along with the existence of several arguments that undermine the claim that social rights are structurally different from civil and political rights, this characterization has a significant impact, from the dogmatic point of view, on the protection of social rights, which are traditionally viewed as non-fundamental rights and, thus, of weakened protection, since they do not have similar protection mechanisms and guarantees as do civil and political rights.

On the one hand, this formulation implies that social rights would be presented as rights subject to legislative definition - in other words, rights that can only be realized by the powers in charge, who would decide what to do with them, without us being able to impose greater limits or liens on that discretionary power, and, on the other hand, ensuring that social rights would not be jurisdictional rights, which is to say they could not be invoked before a court in order for it to establish remedial measures for their violation by political or private actors.

On an axiological plane, what makes a right fundamental is, first and foremost, its claim to protect interests or basic needs, associated with the principle of real equality. In short, it is the general nature of these interests, which apply to everyone, that makes a right inalienable and unavailable. Under this perspective, fundamental rights, human rights and individual rights have similar meanings.

From a dogmatic point of view, however, the situation is somewhat more complex. In general terms, the understanding is that so-called fundamental rights are those that are considered more relevant within a given legal order, relevance which is measured according to the inclusion of the law in other laws that are higher within the internal system, such as constitution, or even international treaties and conventions ${ }^{19}$.

It is possible, therefore, that certain rights, which could be considered fundamental from an axiological point of view, are also so from a dogmatic perspective. But this connection does not always

\footnotetext{
${ }^{19}$ For more on this matter, see FREIRE, A. La garantía en el Estado constitucional. Madrid: Trotta, 1997, p. 1.120.
} 
exist, so that the legal systems can themselves incorporate discriminatory or exclusionary interests and needs as fundamental, always subject to criticism from an axiological point of view ${ }^{20}$.

In any case, contrary to the thesis that social rights are rights of weak and fragile protection, we assert that it is not, in fact, the concrete guarantees of a right that allow it to be categorized as fundamental. On the contrary, it is precisely the inclusion of a right as fundamental, in positive legal system, that requires legal operators to maximize the mechanisms necessary for their guarantee and protection. Therefore, if from an axiological perspective we can say that there is a certain equivalence between the expressions "fundamental rights," "human rights" and "individual rights," from a dogmatic perspective we can say that there is a certain equivalence between the expressions " "fundamental rights" and "constitutional rights." Thus, the absence of legislative or judicial guarantees for a constitutional right, be it civil, political or social in nature, does not mean that it is a fundamental right - on the contrary, it shows that the political and judicial agents have failed to fulfill the implicit duty to act set out in the law. It is not the right that is not fundamental, but rather the political authority that has been negligent or acted improperly, delegitimizing its actions ${ }^{21}$.

In the current legal systems, the recognition of a right as fundamental, in and of itself, implies the attribution of a minimum content and, therefore, the imposition of certain elementary duties onto public authorities, including (or mainly) duties of nondiscrimination, non-regression and progressivity. This does not, of course, prevent the actual scope of certain rights from depending on what the legal system establishes. Some constitutions, such as the Brazilian Constitution of 1988 , describe the content of social rights in a very detailed manner ${ }^{22}$; others only provide a minimal

\footnotetext{
${ }^{20}$ For example, the Constitution of the United States essentially enshrines the right to bear arms as a fundamental right, while the European Constitutional Treaty (2004) establishes a clear priority of market freedoms over social rights.

${ }^{21}$ For more on this matter, see FERRAJOLI, L. et al. Los fundamentos de los derechos fundamentales. Translated by Antonio de Cabo and Gerardo Pisarello. Madrid: Trotta, 2001, p. 45.

${ }^{22}$ The Italian Constitutions of 1947 and he Portuguese Constitution of 1976 are other similar cases. The South African Constitution of 1996 incorporates emerging social rights, such as the right to water, which go beyond traditional rights.
} 
framework for social rights, or relegate these rights to the scope of merely implicit rights ${ }^{23}$. Some constitutions provide a detailed description of the duties imposed onto the public authorities or even private actors with regards to enshrined rights, while others merely mention these obligations ${ }^{24}$.

If inserting a social right into the constitutional text indicates its fundamental nature, it is not an essential requirement, given the principle of indivisibility and interdependence inherent to all rights, since any constitution that includes the principle of equality in matters of basic civil and political rights is ultimately a mandate of generalization that requires the inclusion, at least indirectly, of the social rights related to them. This is currently the case in a number of legal systems that do not explicitly recognize social rights or do not grant these rights the status of fundamental rights. For example, in these legal systems, the right to decent housing has been deduced from other rights, such as the inviolability of one's home, intimacy or private and family life ${ }^{25}$.

When we assert that social rights are subject to legislative definition, the idea that comes to mind is that, along with their constitutional recognition, these rights only become enforceable once they are developed by the legislator, and that the legislator, as the representative of the will expressed at the ballot box, has an almost unlimited discretionary margin to proceed with this development. However, this idea is not tenable.

All rights, and not just social rights, nor the participatory political rights, are rights subject to legislative definition, in the sense that, for their full efficacy, legislative intervention is in one way or another indispensable. The law, both by the formal legitimacy of the bodies from which they originate, and by its potentially generalizable scope, is a privileged source of legal production in modern legal

\footnotetext{
${ }^{23}$ This is seen, for example, in the Constitution of the United States.

24 The Constitution of Ecuador (1996), for example, establishes, in its Article 96, that "The budget shall allocate not less than thirty percent of the central government's current revenues towards education and the eradication of illiteracy."

${ }^{25}$ In the case of López Ostra v. Spain (1994), the European Court of Human Rights (ECHR) found that the lack of control by the public authorities over a polluting industry affecting the health and safety of the people living in its vicinity constituted a violation of the right to privacy and family life. In this case, rights to the environment, health and housing are interrelated.
} 
systems, and constitutes a primary guarantee for the fulfillment of any right.

All fundamental civil, political or social rights require legislative provisions (for example, the effectiveness of the right to health presupposes laws that prevent discrimination in the access to basic health services, or that intervene in the market to ensure basic medicine at a low cost), which may, of course, have different scopes. Greater or lesser regulation may, of course, strengthen or weaken the possibilities of judicial enforceability of the rights in question, but it alone does not prevent those rights from having a minimum content, unavailable to the powers in charge and susceptible, for that very reason, to some type of judicial protection, even in the absence of legislative regulation.

The United Nations Committee on Economic, Social and Cultural Rights has held that the public authorities are, at all times, required to ensure at least the essential contents of each of the rights, even in times of crisis or factual difficulties ${ }^{26}$. Likewise, different laws enshrine the duty of States to respect the minimum or essential content of the rights recognized in constitutions or international conventions and treaties ${ }^{27}$, content that is conditioned by the context in which the law is applied and is subject to continuous redefinition

\footnotetext{
${ }^{26}$ For more on this matter, see Observación General n. 4 (1991).

${ }^{27}$ For example, Article 19 of the Fundamental Law of Bonn (1949), “(1) Soweit nach diesem Grundgesetz ein Grundrecht durch Gesetz oder auf Grund eines Gesetzes eingeschränkt werden kann, muß das Gesetz allgemein und nicht nur für den Einzelfall gelten. Außerdem muß das Gesetz das Grundrecht unter Angabe des Artikels nennen. (2) In keinem Falle darf ein Grundrecht in seinem Wesensgehalt angetastet werden"(Where, in accordance with this Fundamental Law, a fundamental right can be restricted by a law or by virtue of a law, said law must be generally valid, and not only for a specific case. The fundamental right, moreover, must be enunciated in the law, with the indication of the referred article. However, it must not in any case incur in violation of the substance of a fundamental right), as well as Article 18 of the Portuguese Constitution (1976), “(1) The constitutional precepts regarding rights, freedoms and guarantees are directly applicable and bind public and private entities. (2) The law may only restrict rights, freedoms and guarantees in cases expressly provided for in the Constitution, and the restrictions should be limited to those needed to safeguard other constitutionally protected rights or interests. (3) Restrictive laws of rights, freedoms and guarantees must be general and abstract in nature, and must not have a retroactive effect nor diminish the extent and scope of the essential content of constitutional precepts."
} 
over time - the essential content of these rights does not contain an abstract or transcendent conception: the boundary between what we may consider essential or basic and what we may classify as additional or non-essential is always mobile, historical and open.

In any case, this minimum will always be an insurmountable barrier, which requires permanent boundaries and demands a certain integration between justice and politics, between judges and legislators. We defend that the constitutional recognition of social rights, by itself and in any circumstance, including in times of economic crisis, the effective constitutional recognition of social rights, establishes a nucleus that is unavailable to the powers in charge at any time, including the courts, which is why none of these authorities can fail to recognize and thus guarantee such rights for all people, especially those in the most vulnerable situations ${ }^{28}$.

In short, all civil, political and social rights are, structurally or for reasons of political convenience, either rights subject to legislative definition that depends on the discretion of the powers in charge to be effective, or are rights whose positive or negative limits are unavailable to the powers in charge, including to the legislative majorities or the courts. Therefore, we assume the normative ideal of constitutional democracy, of a democracy in which the fulfillment, or lack thereof, of rights related to the physical safety and autonomy of an individual are not alienated to the discretion of any authority.

\section{CRITIQUES OF THE JUSTICIABILITY OF SOCIAL RIGHTS}

Finally, we reject the idea of social rights as non-jurisdictional rights, that is, rights that could neither be demanded nor protected in a before a court of law. The question of whether or not it is a jurisdictional right, is not a matter of absolutes, of simply yes or no rather, it relates to a gradual concept. The justiciability of a right must, above all, be analyzed based on several factors, including preventive,

\footnotetext{
${ }^{28}$ In this sense, according to Pisarello, "Not only would there be minimum or essential content attributable to each civil, political or social right, in isolation, but also a population minimum, composed of the most vulnerable groups, which, especially in times of crisis, should enjoy the priority protection of public authorities" (PISARELLO, G. Los derechos sociales y sus garantías. Madrid: Trotta, 2007, p. 86).
} 
punitive or control aspects, even if all such aspects are aimed at enforcing punishment for the violation of a right, establishing a mechanism which, in one way or another, requires the legislative or administrative bodies to offer a public justification for failing to enforce such rights, and thus for the illegal nature of such omission.

However, when we speak of justiciability of rights, we usually find two central arguments that tend to refute the actions of the courts: on the one hand, the lack of democratic legitimacy of the courts ${ }^{29}$, and on the other, the technical incompetence of judges to deal with economic issues ${ }^{30}$.

\subsection{The argument that judges lack democratic legitimacy}

According to the argument that the courts lack democratic legitimacy, allowing the Judiciary to enforce the fulfillment of social rights in participatory systems of popular representation would introduce an inadmissible antidemocratic element. This would create a scenario in which elected representatives could have their policies overridden by public officials with no political accountability, in the sense that they are not accountable to the electorate, and would ultimately have the final say on these matters. In addition, this level of control would detract from the role that constitutions play in complex contemporary pluralistic societies: by intervening in certain public social policies, jurisdictional bodies would, in fact, indirectly "constitutionalize" an economic model of concrete development, changing the nature of the constitution from an open and pluralist mandate $^{31}$ that accommodates a wide range of political doctrines, to a document expressing the doctrines favored by judges.

\subsection{The argument that judges lack technical competence;}

On the other hand, according to the argument that judges lack the technical competence to deal with economic issues, it would be

\footnotetext{
${ }^{29}$ On the lack of democratic legitimacy of the Judiciary, concerning the Supreme Court of the United States, see BICKEL, A. The least dangerous branch: The Supreme Court at the bar of politics. New York: Yale University, 1986.

${ }^{30}$ Cf. FABRE, C.Social rights under the Constitution. Oxford: Clarendon, 2000, p. 128.

31 On the idea of "Open Constitution," see REVORIO, F. La Constitución como orden abierto. Madrid: Mac Graw-Hill, 1997, p. 3.
} 
truly dangerous to allow judges to intervene on complex issues given the lack of knowledge about specific economic and social issues. Moreover, such interventions would tend to ignore budget constraints and be irresponsible from the point of view of their financial impact, leading to a kind of judicial "populism," a context in which popular participation itself would be weakened, as it would lead citizens to abandon or at least discredit electoral disputes and various forms of social mobilization, favoring the filing of lawsuits ${ }^{32}$. Finally, the courts would still lack adequate tools and procedural mechanisms to allow them to provide the protection that social rights normally require.

And, in fact, such criticisms are not unfounded. However, based on a perspective that seeks to value all possible ways of guaranteeing social rights, we cannot consider them conclusive. More often than not, the lack of democratic legitimacy of the judges is not significant; instead, when they act to protection social rights by controlling actions or omissions of other public powers or even private actors who violate these rights, the courts not only act in accordance with the democratic principle, but can reinforce it by ensuring compliance of the law, and especially of their own constitutional provisions, protecting such rights from unlawful or arbitrary actions. Thus, the courts' actions are legitimate in multiple situations ${ }^{33}$.

\subsection{Judicialization as the materialization of the democratic paradigm;}

In fact, we cannot ignore the phenomenon known as the "juridification surge" (Verrechtlichungsshüb). One must consider the

\footnotetext{
32 On this possible "fetishization" of the use of rights, see BROWN, W.; WILLIAMS, P. La crítica de los derechos. Translated by Isabel Jaramillo. Bogotá: Universidad de Los Andes, 2003.

${ }^{33}$ For example, in the case of Himachal Pradesh State v. Sharma (1986), the Supreme Court of India ordered the government to build a road that had already been the subject of an administrative decision, corroborating the thesis that the government (the Executive Branch) is bound by its commitments to provide a public service by the fact that it cannot act against its own acts (venire contra factum proprium non valet). In 1997, the Supreme Court of Finland upheld the decision of another court, which sentenced a local government to compensate a person who had been unemployed for a long period of time for failing to find him a job within six months, as it had committed to. On these decisions, see PISARELLO, G. Op. cit., p. 91.
} 
fact that, although it has been intensified throughout expansion of the European Welfare State, and can be seen as its necessary byproduct, this phenomenon is present in all contemporary juridical experience.

However, the extension of jurisdictional control is an irrefutable reality, and far from being based on the lack of democratic legitimacy, works towards implementing the democratic paradigm, overcoming the so-called counter-majoritarian difficulty. Thus, at least when it comes to true representative democracy, the protection of fundamental rights and of the principles related to the social and democratic State of law itself cannot be restricted to legislative bodies, which are naturally sensitive to pressures from the majority, and barely sensitive to demands that do represent any immediate electoral benefits, or even those demands that escape the agenda of political priorities established by the "party logic."

In this context, it is precisely the supposed antidemocratic element (the lack of political accountability and the relative independence that emanates from it) that makes the Judiciary an "suitable" instrument (though not the only, and not even the main one) to exercise a certain level of control over the other politically sensitive powers in matters of civil, political and social rights, especially with regard to the barely visible and audible political interests of "minorities" (which, sometimes, are de facto majorities) who are marginalized in traditional representative channels. This is the case of prisoners and immigrants, for example, who often find in the courts the protection which political bodies deny them ${ }^{34}$.

Therefore, jurisdictional control over economic and social policies is not a restrictive expression of democracy; on the contrary, it appears as a true condition for its maintenance over time and for adapting the actions of the political powers to the principles of the social State itself. The control of constitutionality, above all, presents

\footnotetext{
34 "Referring to these assumptions in the United States, Judge Brennan, a member of the Supreme Court, found that 'courts have emerged as a critical force behind efforts to improve inhuman conditions.' And trying to explain the reasons for this role, he argued: 'Isolated as they are from political pressures, and invested with the duty to implement the Constitution, the courts are in the best position to insist that unconstitutional issues be remedied, even if the financial cost is significant." (UPRIMNY, R. Legitimidad y conveniencia del control constitucional a la economía. Revista de Derecho Público de la Universidad de los Andes, Bogotá, n. 12, 2001, pp. 164-5).
} 
itself as a paradoxical instrument for providing access to representative decision-making bodies, guaranteeing the proper functioning of democratic procedures and avoiding subjecting political obligations related to civil, political and social rights to technocracy or to partisanship; however, it is clear that such a justification for judicial intervention on economic and social policies cannot be seen as a tout court justification for judicial interventions. Our argument is restricted to those interventions aimed at the normative implementation of the underlying rights of democratic procedures, including basic social rights, and refuting others, which often tend to restrict the scope of these rights.

On the other hand, introducing judicial controls over legislative majorities, with a view to safeguarding social rights, in favor of minorities who are vulnerable or de facto majorities who are marginalized, would not detract from the "open" nature of the Constitution, nor from political pluralism, nor the political or the democratic principle itself. Rather, these controls would only establish its greater, real possibility of realization, in a manner appropriate to the principle of the social State ${ }^{35}$.

As for the judges' lack of technical competence to deal with economic issues, it is also not an appropriate reason for denying the justiciability of social rights.

Courts are usually called upon to resolve disputes involving significant economic issues. Thus, jurisdictional solutions in labor, tax, succession, economic, corporate and bankruptcy law, for

According to Canotilho (1995, p.9 et seq.), Constitutional "openness" does not equate to neutrality, and if we want to prolong it over time we must be able to preserve the material bases that support the democratization processes: a Constitution that recognizes social rights or that, in the name of the principle of the social State, imposes positive and negative obligations onto the market and public authorities cannot be "neutral" in economic terms, the same way as a Constitution that prohibits torture and guarantees due process is not "neutral" in criminal matters (CANOTILHO, J.J. G. Revisar/la o romper con la Constitución dirigente? Revista Española de Derecho Constitucional, Madrid, n. 43, 1995, p. 9). Thus, according to Uprimny, legislative majorities cannot, for example, invoke the democratic principle to justify a crime-fighting strategy based on the systematic torture and massive nonrecognition of citizens' rights, just as they cannot do so to justify eliminating the right to strike or any deliberate regression with respect to social rights (UPRIMNY, R. Op. cit., p. 190). 
example, concern many questions related to the management of assets, the determination of damages and losses, calculations of interests and loss of profits and other undeniably complex issues, which, for the most part, require some technical knowledge and are not immune to judicial intervention. In addition, judges can resort to experts when ruling on complex issues, even though they are not usually bound by the experts' conclusions.

Likewise, we emphasize that any possible impact of court rulings on social rights, in financial and budgetary matters, cannot be used as an absolute obstacle to the justiciability of social rights. On the one hand, as we have demonstrated, many of the court rulings related to the protection of social rights do not inherently have any major financial or budgetary impact: they include provisional measures against evictions, or court orders aimed at legislators or the public administration, thus adding to the regulatory framework of a given social right. On the other hand, if it is inevitable that many court rulings pertaining to social rights have financial and budgetary impact, the truth is that this is also true with regards to the protection of other civil and political rights, including in the protection of traditional property rights, a which sometimes includes monetary compensation and disbursements not foreseen in the budget ${ }^{36}$.

In fact, the financial and budgetary impact of the Judiciary's protection of civil, political and social rights is unavoidable if we accept the conditions that, at least formally, characterize a constitutional democracy. The existence of certain basic interests, unavailable to the powers in office, implies the existence of an insurmountable limit for decisions on public expenditures. In addition, the limits imposed on decisions concerning public expenditures is a corollary of respect for the minimum or essential content of rights ${ }^{37}$.

However, the fact that the freedom to make decisions on public expenditures is not absolute does not mean that judicial interventions should never take into account not only the budgetary

36 Cf. LANGFORD, M. Judging resource availability. In: SQUIRES, J.; LANGFORD, M. The road to a remedy: current issues in the litigation of economic, social and cultural rights. Sydney: UNSW, 2005, p. 91.

${ }^{37}$ Cf. ARANGO, R. Promoción de los derechos sociales constitucionales por vía de protección judicial. El Otro Derecho, Bogotá, n. 28, 2002, pp. 118 et seq. 
and financial consequences, but also the political and social consequences of their actions. But a certain sensitivity for consequences of its own performance cannot be confused with the pragmatic notion that any intervention by the Judiciary with an economic impact represents a danger to the budget's balance, or constitutes an illegitimate intervention in a field reserved for politics. Furthermore, in practice, the courts have guided their action in this regard by seeking a possible mediation between the guarantee of basic civil, political and social rights and the principle of separation of powers and balancing the budget.

The argument for the lack of resources and the proviso of the possible cannot be considered an absolute and definitive argument to revoke jurisdictional control. On the contrary, the courts have often demonstrated that their involvement is not as complex or costly as the political bodies maintained, by presenting alternative numbers and data that demonstrate the fallacy of certain impossibilities, or have shown that some costs are sometimes deliberately excluded from the numbers and data, such as the future costs of postponing a given policy ${ }^{38}$.

Furthermore, the decisions in question are often not unilateral, but have resulted from a dialogue that is not necessarily condescending with other public powers, urging them to redress unconstitutional actions and omissions related to social rights ${ }^{39}$. In some countries, as in Brazil and Portugal, the courts have issued statements highlighting the unconstitutional elements of a given

\footnotetext{
${ }^{38}$ In this sense, Langford cites the Auton case, of 2000. In this case, the government of British Columbia in Canada resorted to the proviso of the possible argument to deny funding for a treatment program for autistic children. The provincial supreme court rejected the argument, considering that the government had violated the basic right of autistic people of not being discriminated against. When justifying its ruling, the court used two criteria that took the public budget into account. On the one hand, it argued that the costs of the program that would provide assistance to minors at an age of educational and social development would be considerably lower than those required for their long-term treatment if the program were not implemented. On the other hand, it objected to the provincial government's argument that other Canadian regions had implemented similar programs, weakening the argument that the scientific value of the program did not justify a similar expenditure (LANGFORD, M. Op. cit., p. 94).

39 On the European experience, see AJA, E. Las tensiones entre el Tribunal Constitucional y el legislador en la Europa actual. Barcelona: Ariel, 1998.
} 
policy, but falling short of banning the policy in order to avoid undesirable economic or social consequences. In these cases, the courts have provided the legislative or executive body with reasonable time for adapting the measure to the constitution ${ }^{40}$.

Sometimes, the traditional course of the courts against major rights violations has given rise to sentences that are not merely declaratory of unconstitutionality, but true structural injunctions, decisions that determine the concrete measures to be adopted by the public authorities, establish an implementation schedule and setting other measures to ensure the effectiveness of the decisions themselves ${ }^{41}$. In such cases, the seriousness and complexity of the situation also warrants a wide-ranging dialogue between the courts, the public authorities and the affected parties themselves, which also extends to the enforcement stage of the judgment ${ }^{42}$.

One of the mechanisms used by courts to carry out this type of control is the principle of proportionality, which allows them to assess whether a certain public policy is for constitutionally legitimate purposes, whether it is adequate for the achievement of those ends and if this policy uses the possible and least costly means for the rights it affects. This control of proportionality is in fact closely associated with the control of reasonableness, by means of which some courts, such as the South African, have included a "duty of priority for the most vulnerable," that is, the obligation that a given public policy under review offer responses in the short-, medium - and long-term, if not for the whole of society, at least for a considerable sector of the most vulnerable groups, with the most urgent needs ${ }^{43}$.

${ }^{40}$ In Brazil and Portugal, these statements or replies allowed the emergence of control over situations of unconstitutionality resulting from legislative omissions.

${ }^{41}$ According to Fiss, structural injunctions have a long tradition in the United States, where they were used, for example, to introduce penitentiary reforms and policies to eradicate racial discrimination in schools (FISS, O. The law and it could be. New York: New York University, 2003).

${ }^{42}$ The Colombian constitutional court, for example, developed the concept of unconstitutional state of affairs to describe "situations of violation of fundamental rights that are of a general nature - as they affect a multitude of people - and whose causes are structural in nature, that is, they do not normally originate exclusively in the defendant authority and, therefore, their solution requires the joint action of different entities" (Ruling T-153, 1988).

${ }^{43}$ Cf. SUNSTEIN, C. Designing democracy. Oxford: Oxford University, 2001, p. 221. 
In this context, a resolution of disputes based on legal procedures can be easily mentioned in a substantially democratic justification of the jurisdictional function, which seeks to give it not only the last word in matters pertaining to social rights and their guarantees, but the function of preserving the deliberative nature of the legislative process itself and its implementation. From then on forward, one of the main obligations of the political bodies subject to judicial control would be to provide adequate information on the relevant issues pertaining to each case, to listen to the persons affected by a certain public policy, focusing mainly on the vulnerable groups, and to provide the public the reasons for their actions or omissions on the matter.

\section{FINAL CONSIDERATIONS}

In short, public authorities cannot, in fact, be forced to do the impossible. However, what is possible (or impossible) at the economic, social and cultural levels must be proven, not just presumed. As we mentioned above, political bodies must always demonstrate that they are making their best efforts and using all of their resources available to enforce the rights in question; that they are providing sufficient and clear information, and listening to the recipients of the rights in question; that they are striving to control and monitor the effective implementation of existing policies and programs, as well as planning for the future; and that, at the heart of the policies and programs being planned or implemented is the short-, medium or long term solution for the problems that affect especially the most vulnerable and needier groups.

Consequently, the courts can and should control the reasonability of the responses of public authorities to social demands, while respecting the principle of separation of powers and taking into account the consequences of their decisions, but without shying away from its duty to enforce the civil, political and social rights recognized by the Constitution.

\section{REFERENCES}

ABRAMOVICH, V.; COURTIS, C. Los derechos sociales como derechos exigibles. Madrid: Trotta, 2002. 
AJA, E. Las tensiones entre el Tribunal Constitucional y el legislador en la Europa actual. Barcelona: Ariel, 1998.

ALEXY, R. Teoría de los derechos fundamentales. Translated by Ernesto Garzón. Madrid: Centro de Estudios Constitucionales, 1994.

ARANGO, R. Promoción de los derechos sociales constitucionales por vía de protección judicial. El Otro Derecho, Bogotá, n. 28, 2002.

ÁVILA, J. El mínimo vital en la jurisprudencia de la Corte Constitucional. Bogotá: Cinep-Diakonia, 2002.

BICKEL, A. The least dangerous branch: the Supreme Court at the bar of politics. New York: Yale University, 1986.

BROWN, W.; WILLIAMS, P. La crítica de los derechos. Translated by Isabel Jaramillo. Bogotá: Universidad de Los Andes, 2003.

CANOTILHO, J. J. G. Direito constitucional e teoria da constituição. Coimbra: Almedina, 1999.

CANOTILHO, J. J. G. Revisar/la o romper con la Constitución dirigente? Revista Española de Derecho Constitucional, Madrid, n. 43, 1995.

DALY, M. Access to social rights in Europe: Council of Europe Report. Lisbon: Ministry of Social Security and Work, 2003.

FABRE, C. Social rights under the Constitution. Oxford: Clarendon, 2000.

FERRAJOLI, L. et al. Los fundamentos de los derechos fundamentales. Translated by Antonio de Cabo and Gerardo Pisarello. Madrid: Trotta, 2001.

FISS, O. The law and it could be. New York: New York University, 2003.

FREIRE, A. La garantía en el Estado constitucional. Madrid: Trotta, 1997.

HART, H. El concepto del derecho. Translated by Genaro Carrió. Buenos Aires: Abeledo-Perrot, 1963.

HOLMES, S.; SUNSTEIN, C. The cost of rights: why liberty depends on taxes. New York: Norton, 1999.

LANGFORD, M. Judging resource availability. In: SQUIRES, J.; LANGFORD, M. The road to a remedy: current issues in the litigation of economic, social and cultural rights. Sydney: UNSW, 2005.

UNITED NATIONS. OFFICE OF THE UNITED NATIONS HIGH COMMISSIONER FOR HUMAN RIGHTS. General comment $n .4$ of the Committee on Economic, Social and Cultural Rights. 2001. Available at (in Spanish):

<http://www.ohchr.org/spanish/about/publications/docs/fs25_sp.htm>.

Retrieved on August 13, 2016. 
PISARELLO, G. Los derechos sociales y sus garantías. Madrid: Trotta, 2007.

REVORIO, F. La Constitución como orden abierto. Madrid: Mac Graw-Hill, 1997.

SCHWARZ, R.; THOMÉ, C. Judicialização e administração pública no Brasil: notas a respeito da concretização dos direitos fundamentais sociais. Sociedad y discurso, Aalborg, n. 28, 2015.

SHUE, H. Basic rights: subsistence, affluence and U.S. foreign policy. New Jersey: Princeton University, 1980.

SUNSTEIN, C. Designing democracy. Oxford: Oxford University, 2001. UNITED NATIONS. ECONOMIC AND SOCIAL COUNCIL. General comment $n$. 3. 1990. Available at: <https://confdts1.unog.ch/1\%20SPA/Tradutek/Derechos_hum_Base/CESCR/00_1_obs_ grales_Cte\%20Dchos\%20Ec\%20Soc\%20Cult.html\#GEN3>. Retrieved on August 13, 2016.

UPRIMNY, R. Legitimidad y conveniencia del control constitucional a la economía. Revista de Derecho Público de la Universidad de los Andes, Bogotá, n. 12, 2001. 